Working Paper No. 36, 2021

Slaves Who Owned Slaves in Nineteenth-Century Bahia, Brazil

João José Reis
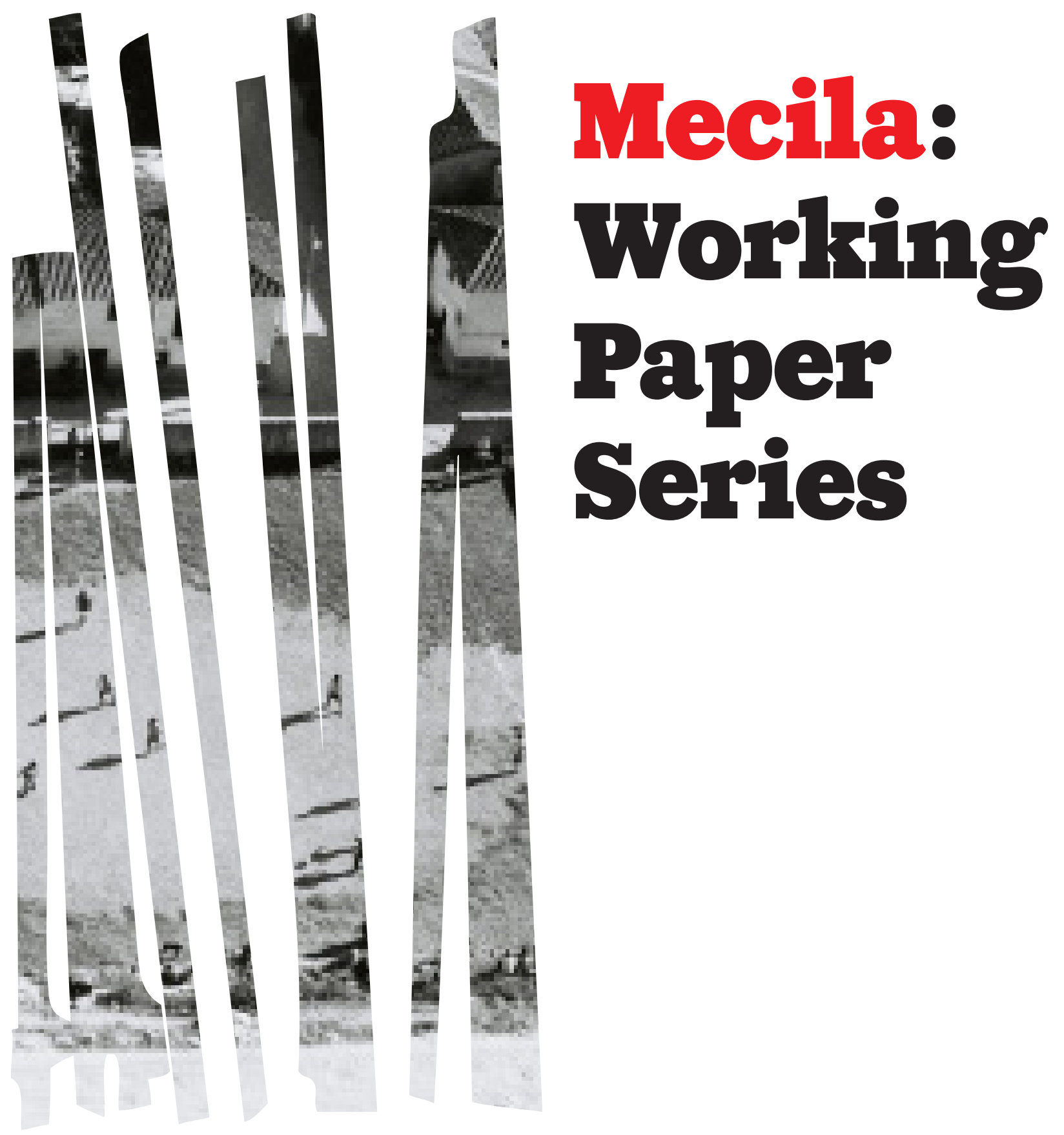

Paper

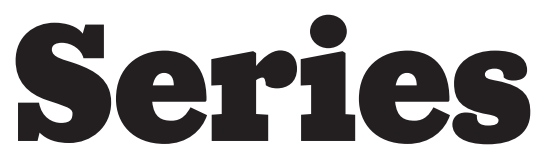


The Mecila Working Paper Series is produced by:

The Maria Sibylla Merian International Centre for Advanced Studies in the Humanities and Social Sciences Conviviality-Inequality in Latin America (Mecila), Rua Morgado de Mateus, 615, São Paulo - SP, CEP 04015-051, Brazil.

Executive Editors: Susanne Klengel, Lateinamerika-Institut, FU Berlin, Germany Joaquim Toledo Jr., Mecila, São Paulo, Brazil

Editing/Production: Raquel Gil Montero, Fernando Baldraia, Joaquim Toledo Jr., Paul Talcott

This working paper series is produced as part of the activities of the Maria Sibylla Merian International Centre for Advanced Studies in the Humanities and Social Sciences ConvivialityInequality in Latin America (Mecila) funded by the German Federal Ministry of Education and Research (BMBF).

All working papers are available free of charge on the Centre website: http://mecila.net

Printing of library and archival copies courtesy of the Ibero-Amerikanisches Institut, Stiftung Preußischer Kulturbesitz, Berlin, Germany.

Citation: Reis, João José (2021): "Slaves Who Owned Slaves in Nineteenth-Century Bahia, Brazil", Mecila Working Paper Series, No. 36, São Paulo: The Maria Sibylla Merian International Centre for Advanced Studies in the Humanities and Social Sciences Conviviality-Inequality in Latin America, http://dx.doi.org/10.46877/reis.2021.36.

Copyright for this edition:

(C) João José Reis

This work is provided under a Creative Commons 4.0 Attribution-NonCommercial-NoDerivatives 4.0 International License (CC BY-NC-ND 4.0). The text of the license can be read at https:// creativecommons.org/licenses/by-nc-nd/4.0/legalcode.

The Maria Sibylla Merian International Centre for Advanced Studies in the Humanities and Social Sciences Conviviality-Inequality in Latin America cannot be held responsible for errors or any consequences arising from the use of information contained in this Working Paper; the views and opinions expressed are solely those of the author or authors and do not necessarily reflect those of the Maria Sibylla Merian International Centre for Advanced Studies in the Humanities and Social Sciences Conviviality-Inequality in Latin America, its research projects or sponsors.

Inclusion of a paper in the Mecila Working Paper Series does not constitute publication and should not limit publication (with permission of the copyright holder or holders) in any other venue.

Cover photo: (C) Nicolas Wasser 


\title{
Slaves Who Owned Slaves in Nineteenth-Century Bahia, Brazil
}

João José Reis

\begin{abstract}
It was not uncommon in Brazil for slaves to own slaves. Slaves as masters of slaves existed in many slave societies and societies with slaves, but considering modern, chattel slavery in the Americas, Brazil seems to have been a special case where this phenomenon thrived, especially in nineteenth-century urban Bahia. The investigation is based on more than five hundred cases of enslaved slaveowners registered in ecclesiastical and manumission records in the provincial capital city of Salvador. The paper discusses the positive legal basis and common law rights that made possible this peculiar form of slave ownership. The paper relates slave ownership by slaves with the direction and volume of the slave trade, the specific contours of urban slavery, access by slaves to slave trade networks, and slave/master relations. It also discusses the web of convivial relations that involved the slaves of slaves, focusing on the ethnic and gender profiles of the enslaved master and their slaves.
\end{abstract}

\section{Keywords: slavery | enslaved slaveowners | nineteenth-century | Bahia | Brazil}

\author{
About the Author: \\ João José Reis teaches History at the UFBA (Federal University of Bahia). His research \\ has focused on the following topics: social and cultural history of slavery and the slave \\ trade; slave resistance; social movements, and attitudes towards death. He is a lifetime \\ Honorary Fellow of the American Historical Association and received the Machado de \\ Assis Lifetime Achievement Award from the Academia Brasileira de Letras in 2017. He \\ is the author of several books, the latest being Ganhadores: a greve negra de 1857 na \\ Bahia (Companhia das Letras, 2019). He was a Senior Fellow at Mecila in 2019.
}




\section{Contents}

1. Introduction 1

2. Law and Customs 3

3. Enslaved Masters and their Slaves $\quad 6$

4. Enslaved Slaveowners in Manumission Bids 11

5. Conclusion 16

6. Abbreviations 19

7. Bibliography 19 


\section{Introduction}

The phenomenon of freed persons (ex-slaves) who owned slaves has been sufficiently covered in the literature about slavery in Brazil. ${ }^{1}$ Freedmen and women represented a large sector of Brazil's population since the mid-eighteenth century, at least, and many prospered after overcoming slavery through manumission, which they usually bought or obtained with conditional clauses. After being manumitted, slaves often became property holders, and not a few owned one or two slaves just like the free people did, especially in urban settings. Investment in slaves was the main road towards prosperity, besides being a major symbol of freedom in colonial and post-colonial Brazil ( Klein and Luna 2009; Frank 2004; Reis 2016, among other).

However, in Brazil, it was not uncommon for slaves themselves to own slaves. Slaves as masters existed in many slave societies and societies with slaves. ${ }^{2}$ In his survey of slavery around the world, in diverse periods, sociologist Orlando Patterson goes as far as to say that, unlike slaves' property in landholdings and currency, the servus vicarius (the slave of a slave), to use the Roman legal definition, was "a universal occurrence" (Patterson 1982: 184). ${ }^{3}$ However, as far as I could gather in my examination of the pertinent literature, there is scant evidence of this institution's existence in modern era slave societies of the Americas, the plantation-oriented Caribbean included. ${ }^{4}$ More common, though not pervasive at all, was the presence of slaves who bought their freedom using other slaves as substitutes, which also thrived in Brazil. But even these should be better scrutinized beyond considering substitution a mere method of payment for one's freedom, because it implied the social, if not legal recognition of a slave's property rights.

The enslaved slave master has so far received limited attention from historians in Brazil. An investigation on the theme was conducted by Robson Costa, who examined farms of a Benedictine religious order in eighteenth and nineteenth-century Pernambuco province in the Brazilian northeast. He argues that the friars employed a paternalistic

1 I thank the members of the research group Escravidão e invenção da liberdade at the Programa de Pós-Graduação em História, UFBA, for their comments, Marina Barbosa for preparing the statistics, and Joaquim Toledo Jr. for preparing and copy-editing the final text. I equally thank the Conselho Nacional de Desenvolvimento Científico e Tecnológico - CNPQ for funding this research, and Mecila for a grant that allowed me to rewrite and improve it during a two-month residence at CEBRAP.

2 For the difference between "slave societies" (in which slaves constitutes the dominant labour force and form a clearly identifiable "class") and "societies with slaves" (where slavery only exists as a nondominant institution), see Finley 1980 and 1968.

3 On the following page of his book, however, Patterson writes that the institution of the peculium (slave savings, which included slaves) in general was "very nearly universal" (Patterson 1982: 185, my emphasis).

4 I found one exceptional reference, the Spanish Crown slaves in the El Cobre mine in Cuba (Díaz 2000 , ch. 7). For a couple of examples from the sixteenth and seventeenth centuries regarding more conventional slaves, see Fuente 2004. 
strategy of slave control and missionary work that involved promoting legitimate slave families, some access to manumission, and allowing them to own property: houses, cattle, harvest, and money, in addition to slaves (Costa 2020. esp. ch. 4). ${ }^{5}$

The concept of paternalism used by Robson Costa is old currency in the historiography of slavery. ${ }^{6}$ But the key term, one that embraces most dimensions and goes beyond the concept of paternalism - without dismissing it as a strategy of class control -, is negotiation. Although negotiation between slave and master played out in obviously imbalanced power relations and unfathomable inequality, many masters adopted it as a means to ease tensions with and enhance labour productivity from their slaves without, of course, retreating from the use of the whip and other coercive methods whenever they found it necessary. The point is: for many masters, the whip was not the only or even the most effective means of exerting slave control and reliable work performance, and this was particularly true for less affluent and even poor masters, who were more susceptible to the many forms taken by their slaves' resistance efforts, which included, besides everyday non-cooperation - the so-called day-to-day resistance — flights, aggression, and even murdering masters and members of their families. ${ }^{7}$

In the following pages, I will discuss how the ownership of slaves by other slaves played out in the first half of nineteenth-century Salvador, the capital of Bahia province, an important area of sugar plantation in Brazil since the late sixteenth century. Nineteenthcentury Salvador was a densely African city, with about 60 percent of its slave population born overseas. Slaves in general (Africans and locally-born, or creoles) represented 42 percent of the estimated total population of close to 70,000 souls in the late 1830 s (Reis 2003: 24, 27). Slaves numbered about 30,000 people - unfortunately, no reliable census is available for that period - and slaves who owned slaves represented a tiny proportion. A study by Daniele Santos de Souza concluded that, of the 14,417 persons who took their slaves for baptism in two parishes of eighteenth-century Salvador, only 124 were enslaved masters, or less than 1 percent (Souza 2017). In my investigation in parish records, I found a higher proportion of 2.7 percent (29 cases), while the free were 69.6 percent and the freed 27.7 percent of baptisms performed in one of the main parishes of Salvador, the Conceição da Praia - also included in Souza's survey - which was located in the port district. As for slaves who used other slaves in manumission bids, they represented almost the same proportion, 2.4 percent of

5 See also Nogueira 2011: 168, who identified thirteen enslaved overseers who owned 44 slaves on the vast farmlands belonging to the absenteist Guedes de Brito family in eighteenth-century Bahia. However, the author does not elaborate on her findings.

6 On paternalism see Genovese 1974. For Brazil, among others, Chalhoub 2003.

7 About negotiation in tense slave/master relations, see Reis and Silva 1989. About day-to-day resistance, see the classic, pioneer article by Bauer and Bauer (1971), originally published in 1942. A more recent discussion of the concept is Scott (1992). 
all manumissions during the same period. Despite its proportionately small size, by studying this privileged group of slaves, more can be learned about larger issues, namely the peculiar dynamics of slavery in Bahia, particularly how property rights by the enslaved worked. ${ }^{8}$

\section{Law and Customs}

How did slaves become slave owners? I have found only two answers for this question: 1) donation, mainly post-mortem bequests by free or freed relatives or masters, of which I located just a few examples for the eighteenth century in documents and secondary sources; ${ }^{9}$ and 2 ) more frequently, through the purchase of captives in the slave market. My investigation will concentrate on this latter practice, with a warning that I have not found evidence of the former method of acquisition in nineteenth-century Salvador, except the case of an African freedwoman who bequeathed a slave to her still enslaved son. ${ }^{10}$

No legislation in Brazil guaranteed the possession of any property by a slave. Regarding slaves specifically, the Roman legal tradition of servus vicarius was not incorporated into the colonial Portuguese legal code (the Philipine Ordinances) still in force in independent Brazil for things related to slave property. However, the peculium (the slave's savings), though not recognized in positive legislation, became a common law right negotiated between slaves and masters. Jurist Perdigão Malheiros pointed this out in a famous legal treatise in 1867 - when one did not have to be a jurist to know this was happening - but regarding specifically the Roman institution of the servus vicarius he wrote, peremptorily, that it "has had no application in Brazil". ${ }^{11} \mathrm{He}$ did not consider that slaves could become a form of peculium, and one that was not unknown in his own time. Malheiros was obviously wrong, probably because this phenomenon was not as generalized in Brazil's Southeast where he lived and collected his data. Had he lived in Bahia he surely would have concluded otherwise.

Just as the law recognized masters as the ultimate authority to let their slaves own a peculium, they could (they were not forced to, but they could) allow their slaves to buy,

8 Proportions based on data from baptismal records of the Nossa Senhora da Conceição da Praia parish for 1824-1830, years of intense transatlantic slave trade activity to Bahia.

9 For example, on eighteenth-century Rio de Janeiro, Autos cíveis de justificação entre partes: Paula Pinta de Mello, escrava de Ursula das Virgens, com licença da mesma. Campos, $3^{\circ}$ Cartório, maço 31 (I thank Silvia H. Lara for sharing with me her notes on this document); and Sweet (2011: 95-96).

10 "Antonio Muniz Barreto de Aragão para o presidente da província", Feb. 14, 1849, APEB, Polícia, maço 6306.

11 On peculium, see Malheiros [1867] 1976: 64. See also the mid-eighteenth-century treatise Cortez Bremeu 1749: 20-23. For the complex Roman case, see Buckland 1908: 239-249. For the specific case of the slaves of the Roman emperor, see Weaver 1964. 
inherit, sell, or manumit other slaves. Therefore, parish priests usually did not bother to ask questions when a slave brought his/her own slave to be baptized. However, sometimes priests did not let it go so easily, and then a shadow of the enslaved master's master appears in the documents. For instance, Ambrozio, a Hausa slave, took Rosa, the infant daughter of his African slave Felicidade, to stand baptism in 1831, and the parish priest decided to inquire Ambrozio's master about little Rosa's property status. Having done so, he penned on the baptism book that Ambrozio's master "had declared in writing that he recognized as the slave of the said slave Ambrozio the above mentioned Felicidade, and therefore all of her children", strictly following the enslaved womb legal tradition. Apparently, the priest had forgotten that three years before, without further questioning, he had baptized Felicidade, little Rosa's mother, and another female African as Ambrozio's property. ${ }^{12}$

As this incident suggests, slaves were not completely free to play the role of masters, at least not before the legal system and, sometimes, the ecclesiastic establishment, even if privately it was a different matter. Two manumission documents are especially eloquent on this issue. One of them, written in 1841, reads:

I, Antonio da Costa, of the African nation, slave as I am of my mistress Dona Josefa Maria da Silva, I say that I am the owner of a slave woman by the name of Benvinda, also an African, which property is clear and free of any judicial dispute, and having received from the said slave four hundred mil-reis, and being the resolve of my above mentioned mistress, and also mine, I manumit the said slave and I set her free from now on, and she will enjoy her freedom as if she had been born free by virtue of this [document] that I make of my own and free will, without being constrained to do so by any person whatsoever, and I ask the Justice of His Imperial Majesty in every court to abide by and protect what it is herein contained (APEB, LNT, 270, fl. 109v).

This manumission paper clearly exposes what was involved in this kind of property ownership, its grey zone: first, that the right of a slave to own another slave had to be duly recognized by the master of the enslaved master - this was positive law; second, the enslaved master could exercise fully and enjoy the fruits of his enslaved property, which meant the right to allow his/her slave to save money and use it to buy his/her freedom just like any other master; this was customary law. In this document, the enslaved master appears as the decision-maker, the grantor of the manumission contracted with his slave - "I set her free from now on", "I make [this document] of my own free will", said the slave - although he still needed the consent of someone above his rank, namely a mistress, to validate his decision before the law and to consent his

12 ACMS, LRBCP, 1826-1834, fl. 108 (Sept. 2, 1827); fl. 179v (April 24, 1829); and ACMS, LRBCP, 1834-1844, fl. 18 (Sept. 12, 1834). 
female slave to fully enjoy her freedom. The recognition of vertical links by all involved pervades this episode, from the slave being manumitted all the way to His Majesty the Emperor of Brazil, the guarantor of the country's legal order.

In another freedom letter from 1852, it was Clara Jesuina Teixeira, the enslaved master's mistress, who emerges as the freedom grantor, though conceding to the will of Olegário, her slave:

By means of this letter [of manumission] signed by myself alone, I grant freedom to the African [by the name of] Francisco, [of] Mina [nation], so he may enjoy it as if he were born of a free womb, and I do so because my slave and his master, the African Olegário, asked me to do so, and he [Francisco] may enjoy it [his freedom] from today and forever, and I beg all authorities of this Empire to recognize it, considering it legitimate and reliable (APEB, LNT, 302, fl. 55v).

I have mentioned documents, both ecclesiastical and civil, that can be defined as public records. However, there were also private papers drawn in, and apparently slaves counted on these as proof of property. Disappointingly, I have located only one such document. In 1833 Manoel Joaquim Ricardo, a Hausa enslaved merchant, bought his first slave, an African-born girl, approximately twelve years of age, named Thomazia. The bill of sale of this transaction reads that "Senhor Manoel Joaquim Ricardo" was the new owner of the slave girl, and her former master emphasized that "the said Senhor [a slave] could possess her as she belongs to him from this day and forever [...]". ${ }^{13}$ It is not a small matter that the seller dignified the enslaved buyer by calling him senhor, a strong sign of social esteem. Ricardo's owner was in part responsible for this: in a civil case to which this bill of sale is appended, the slave declared that his master, a prosperous merchant and a slave trader, allowed him to live and work on his own, and to freely hold property, including slaves. When Ricardo gained his freedom, eight years after buying his first slave, he already owned at least another four, having become a transatlantic slave dealer himself (Reis 2016).

Masters who allowed their slaves to possess slaves, in return, counted on their loyalty, obedience, and above all, their hard work (or "good services"). Thus, in most freedom letters, we find expressions such as "for the good services" rendered; for the slave's "good conduct, loyalty and friendship"; "for the love, loyalty and obedience, and for having served us well"; and so on. ${ }^{14}$ These words were written on freedom letters in which slaves paid their way out of bondage with other slaves they owned.

13 Bill of sale by João Coelho da Silva, Dec. 12, 1833, APEB, Judiciária, 51/1821/04, fl. 433.

14 APEB, LNT, 212, fl. 87 (1822); LNT, 212, f. 169 (1824); LNT, 254, fl. 27v (1828); LNT, 222, f. 210 (1828); and LNT, 236, fl. 206v (1831). See, incidentally, Belini 1988. 


\section{Enslaved Masters and their Slaves}

The nature of urban slavery favoured the purchase of manumission, just as it favoured the purchase of slaves by slaves. In Salvador, as in other cities all over the Americas, slaves worked according to the hiring-out system, in which the ganhador (earner, for a male slave) and ganhadeira (earner, for female) worked in all sorts of petty business, mechanical trades and services (mainly carrying objects and people, the latter in sedan chairs), and could keep part of their daily gains, usually around 30 percent. This was not wage labour but paid autonomous, "informal" or piecemeal labour, often doubled with unpaid domestic work for the master family. Success depended on a number of variables, beginning with the specific contract negotiated with masters - based on some sort of average market value - but also experience, the kind of trade performed and location of activities in the geography of the city, the quality of the instrument of work (a nice sedan chair instead of a worn-out one, for instance). Organization of the labour market was also important, and here solidarity played a big role. Africans were organized along ethnic lines - or according to their "nations" — around dozens of male-only workgroups spread throughout the city; these groups were called cantos (meaning both street corner, where ganhadores usually gathered, and chant, for ganhadores performed their work singing); each canto was led by a "captain", who should be familiar with the service market, especially personal and trustworthy connections with clients. On the other hand, the marketing of goods in the streets was one of the most profitable occupations and was usually held by African female enslaved and freedwomen. The hiring-out system represented a key mechanism for slaves to amass savings (peculium) and eventually buy their freedom within approximately ten years of captivity. However, some would rather buy slaves than freedom, depending on the willingness of both bondpersons and mainly that of their masters. ${ }^{15}$

Slaves who owned slaves were not regularly registered in sources typical in the study of slaveholding property, such as tax rolls, notary books, and probate records. The reason for the silence is simple: slaves did not have a legal status that would allow them to appear as titled property holders in these documents. However, as I mentioned before, they often emerge in baptismal records and manumission papers, in the latter when freedom was paid with another slave as a substitute. I have also found a few enslaved masters exceptionally registered in notary books and probate records, usually by the resolve of their masters.

Considering all sources together, I have located 507 enslaved masters who owned 540 slaves in Salvador in the first half of the nineteenth century, the majority (412

15 On African labour in nineteenth-century Salvador, see among other titles, Andrade 1988 and Reis 2019. 
enslaved masters and 433 slaves) mentioned in manumission records. These findings certainly do not reflect all slaves involved in this particular arrangement since numerous documents disappeared or were damaged to the point of illegibility. In addition, much of the phenomenon in hand was never documented but kept within the private realm of master/slave dealings. Considering all these circumstances, I would suggest that the number of slave-owning slaves and their slaves could be at least double what I could so far detect in the archives for the period under consideration.

With rare exceptions - I only found one - baptism records reveal how "normal" it was for slaves to simply take their slaves to a church to baptize them. Besides being a certificate of the person's admission in the Catholic community, baptism registers also functioned as proof of ownership in the absence of or confirming other documents, such as a private bill of sale. Either when they were born locally and baptized as infants (inocentes), or when they were adults freshly brought from Africa, slaves were regularly taken by masters to a church to be baptized following (in the case of African-born adults) a superficial Christian indoctrination. On that occasion, parish priests would usually produce a detailed entry in the baptism book, which included the name of both the slave and that of the slaveowner, the status of the owner (free, freed, or enslaved), his or her parish and sometimes the streets where they resided, names, ethnicity/skin colour, and status of the godfather and, exceptionally, of the godmother, also followed by his/her parish of residence. For example:

I solemnly baptized, and lay the Holy Oil on Joaquim, Nagô [meaning Yoruba speaker], twenty-two years of apparent age, the slave of Benedicto, Hausa, himself a slave of Dona Ponciana Isabel de Freitas, white, widow, a resident at Cais da Loiça; stood godfather Domingos Lopes de Oliveira, Benguela, a freedman, bachelor, resident at Santo Antonio Além do Carmo parish (ACMS, LRBCP, 1826-1834, fls. 78, Jan. 28, 1817).

However, not all priests were so careful in their annotations. Many would identify African masters without indicating their legal status or do it in some cases but not others. The most populous urban parish of Salvador, the Sé (See), the archbishop's seat, is a case in point. For the first half of the nineteenth century, its parish priests conceived a separate baptism book for the enslaved only. Among the hundreds registered, not one was said to belong to another slave, which would be atypical for such a large flock. Black masters are there, but in most cases, their legal status was not recorded, and when they were, they appeared as either free or freed. What is available in baptism records about the enslaved slave master and their slaves is, therefore, only part of a much larger picture. 
I have so far found 107 slaves who were taken to the baptism font or, a tiny minority, found in diverse sources (except manumission documents, which I counted and will discuss separately further ahead). ${ }^{16} \mathrm{~A}$ large number, 46 , were baptized in the Nossa Senhora da Conceição da Praia (already mentioned here), and the Nossa Senhora do Pilar parishes, which makes this urban, port district a major investigation target. This was the commercial heart of Salvador and the residence of local and foreign merchants — including slave traders and their slaves — and freed persons who worked as sailors, stevedores, porters, peddlers, carpenters, and other trades, in this case particularly those linked to the naval industry.

Table 1 displays both baptisms and manumissions involving enslaved masters and their slaves (more on manumission later), and they were unevenly distributed in time. For instance, 33.3 percent of baptisms and 27.8 percent of manumissions were registered between 1826 and 1830. In the Conceição da Praia parish alone, in the short period between 1827 and 1830, twelve African slaves took their fourteen slaves to the parish church for baptism, two of whom owned at least two slaves.

Table 1: Enslaved Slaveowners in Baptism and Manumission Records: Salvador, 1800-1850

\begin{tabular}{|l|r|r|r|r|}
\hline \multicolumn{1}{|c|}{ Years } & \multicolumn{1}{|c|}{$\begin{array}{l}\text { Baptism } \\
\text { Records }\end{array}$} & \multicolumn{2}{c|}{$\begin{array}{l}\text { Manumission } \\
\text { Records }\end{array}$} & \multicolumn{1}{c|}{$\%$} \\
\hline to 1810 & 10 & 10.1 & 44 & 10.7 \\
\hline $1811-15$ & 13 & 13.1 & 37 & 9.0 \\
\hline $1816-20$ & 8 & 8.1 & 39 & 13.6 \\
\hline $1821-25$ & 8 & 8.5 & 56 & 27.8 \\
\hline $1826-30$ & 33 & 33.3 & 114 & 11.2 \\
\hline $1831-35$ & 9 & 9.1 & 46 & 18.0 \\
\hline after 1835 & 18 & 17.8 & 74 & 100 \\
\hline Total & 99 & 100 & 410 & \\
\hline
\end{tabular}

Source: ACMS, Registros de batismos de Salvador; and APEB, Livro de Notas do Tabelião.

*Only manumissions for which I could establish a precise date.

The distribution of figures in Table 1 is related to the dynamics of the transatlantic slave trade. Figures for the first half of the nineteenth century indicate this was the most intense period in the history of the Brazilian slave trade generally. During the last fifty years of this trade - which was finally abolished precisely in $1850-2.1$ million enslaved Africans disembarked on Brazilian soil, representing 67 percent of all

16 For an investigation on eighteenth-century Salvador, using the same source, see Souza 2017. 
those imported in the course of 350 years. It was the golden age of the Luso-Brazilian slave trade. (Brazil became independent from Portugal in 1822, and Bahia in 1823). Although most Africans came to Brazil from West-Central Africa, mainly from Angola, West Africa stood as the main supplier for Bahia, about 306,000 in 423,000 between 1800 and $1850 .{ }^{17}$ Slaves were imported into Bahia mostly, and increasingly, although not exclusively, from ports located on the Bight of Benin, such as Ouidah, Porto Novo (both in present-day Republic of Benin), Badagry, and Lagos (both in present-day Nigeria). Once in Bahia, slaves were sent in their vast majority to sugar plantations in the fertile Recôncavo region, located around the Bay of All Saints, on the southern tip of which lay the city of Salvador, which also employed thousands of them.

The increase in the supply of slaves was even higher than an increasing demand in at least one specific conjuncture. By the mid-1820s (which coincided with the fall of Oyo Ile, the capital of the powerful Yoruba kingdom, and the spread of conflict in Yorubaland) Bahia had become a buyer's market. ${ }^{18}$ In addition, in 1826 the country celebrated a treaty with England (in exchange for British recognition of Brazil's independence from Portugal) that would force the Brazilian Empire to abolish the slave trade within four years (Bethell 1970). Brazilian slave traders believed their days of prey were nearing the end, and they intensified their activities between 1826 and 1830. In the case of Bahia, they were favoured by the large supply of captives from the Yoruba wars. ${ }^{19}$

Although the rise in the volume of African imports was a national trend, the available figures strongly suggest that it was more pronounced in Bahia. In Bahia, there was an increase of 170 percent in the volume of slaves imported from Africa between 1825 and 1829 (from 6,037 to 16,297 slaves), while in Brazil as a whole, the hike reached 73 percent (from 42,171 to 72,949). Bahia imported close to 60,000 African captives in the 1826-1830 quinquennium, 91 percent of whom from the Bight of Benin. Bahia's slave market came close to saturation, not only because of these high figures during this period but because the number of captives imported had also been high in previous years. Although slave prices did not fall drastically in 1826-1830 - for demand was also on the rise - it still allowed petty investors to speculate and expand their exploits, for, in tandem with larger consumers of African labour, they were attentive to Atlantic politics and also reacted positively to the proximity of the year when the slave trade should become illegal.

For the slave trader doing business on African shores, the occasion was even brighter. The mean price of a slave - measured by the main Bahian exchange commodity in the African market - sunk from close to 19 rolls of tobacco to close to 10 rolls

17 All slave trade figures in this paper are from TSTD 2019. See also Eltis and Richardson 2008.

18 On the rise and fall of Oyo, see the classic study by Law 1977.

19 For the same trend in Rio de Janeiro, see Florentino 1997. 
between 1821-25 and 1826-30, a decline of almost 50 percent. In Bahia, the fall was not so pronounced because the demand was also high. Between 1820 and 1830, the average value of a slave woman fell by 13 percent, and that of a man by 17 percent (Nardi 1996: 263; Mattoso, Kátia M. de Queirós 1979: 109).

However, the just mentioned Bahian figures derive from probate records, which did not reflect directly the negro novo or boçal (recently disembarked) market specifically, since slaves listed in probate documents were of all ages, occupations, and health conditions, besides being undervalued for inheritance taxation purposes. We can, however, detect a trend in price fluctuation in those documents, and there was indeed a fall in the last five years of the legal slave trade, i. e., between 1826 and $1830 .^{20}$

We do not know the specific characteristics of slaves being bought by other slaves, such as age, strength, and above all, health conditions. Probably at least some small buyers acquired much cheaper slaves who appeared to be sick but somehow survived the seasoning phase, recovered their health, were taught rudiments of Catholic prayers, and then baptized or used as substitutes in manumission bids. ${ }^{21}$ I have found evidence that this was happening, but it was not possible to establish the extent of the practice. I suspect it was not widespread, for recently imported slaves bought by other slaves do not appear in death records of the same period.

There are other, probably more important, reasons to explain the access of slaves to the slave market in Bahia, namely participation and connections in, or understanding of mercantile networks. Enslaved street workers had daily contact with slave traders, for whom they worked as porters and stevedores, for example, and from whom they could acquire affordable captives from Africa, or even on pre-paid demand; ganhadores often had links with African merchants in the Bight of Benin itself; they could also be involved in the transatlantic commerce as sailors on slave ships; masters of these enslaved slave buyers were frequently transatlantic traders and/or ship captains. For example, on August 5, 1810, Joaquim was taken by his master, Manoel, to the Conceição da Praia parish church to be baptized. They were both slaves. Manoel's master, Antonio Narciso, was a very active slave ship captain. In eight voyages that he made between 1812 and 1825, Narciso carried 2,600 captives, mainly from the Bight of Benin and Cabinda (northern Angola) to Bahia. Narciso sold Joaquim to his slave Manoel, or the

20 The slave trade from areas in Africa situated above the Equator line was prohibited by a series of agreements between Portugal and the UK between 1815 and 1818. The Bight of Benin, from where most Bahian captives were imported, was located in that prohibition zone, but slave traders would declare port authorities in Bahia that they were bound to Angolan ports (mainly Molembo), where the slave trade was still legal, but would sail instead to ports on the Bight of Benin.

21 It was a common practice the purchase of low value, recently arrived sick Africans who were "refused" by the market. They were treated, cured, and then resold for a good price. See Wissenbach 2009. 
latter bought him directly in Africa in case he belonged to his master's ship crew. There are many other stories with similar plots. ${ }^{22}$

\section{Enslaved Slaveowners in Manumission Bids}

Manumission by substitution is mentioned in several studies on slavery in Brazil, and it was particularly strong in Bahia. ${ }^{23}$ Still, it has been discussed only as a means of payment, not as a more complex institution related to property rights of slaves by other slaves. For Salvador, specifically, a study by Stuart Schwartz on the first half of the eighteenth century found eighteen cases of substitution, or 3 percent of all paid manumissions. For the longer period of 1808-1888, Mieko Nishida found 35, or 2.6 percent in a sample of 1,332 paid manumissions (Schwartz 2001: 205-206; Nishida 1993). ${ }^{24}$

I have located, for the first half of the nineteenth century alone, 412 slaves who offered 433 other slaves in return for their freedom and in a few cases for that of their children. (The difference in the numbers results from more than one slave being offered in eleven manumissions, usually a mother and her child). Like the baptism records, these manumissions were concentrated in specific periods, namely the years 182630. Table 1 suggests that many slaves were buying slaves to eventually use them as substitutes in their manumission bids. However, I found only two enslaved masters in both baptism and manumission records, which suggests that baptisms represented but a small fraction of transactions in the Bahian slave market.

Manumission papers pertaining to slaves who owned slaves represent only a flash in the lives of those involved with that kind of transaction. Still, they often suggest that the future freed persons were not mere intermediaries in the transference of property between two owners, the enslaved slaveowner and his own master or mistress. Even if slaves bought other slaves having in mind manumission by substitution in the short run, as many did, they had first to train their substitutes to operate under servitude before masters considered the deal concluded satisfactorily. That would involve

22 ACMS, LRBCP, 1809-1815, fl. 282v; ACMS, LRBCP, 1809-1815, fl. 261v; APEB, LNT, vol. 215, fls 146-147; and for Narciso's slave trade voyages, see TSTD 2019, voyages \# 9 (1817); \# 574 (1825); \# 7334 (1812); \# 7356 (1813); \# 7396 (1815); \# 47178 (1812); \# 48667 (1818); and \# 48826 (1819).

23 An expanded discussion of this topic will soon be published in "'Por sua liberdade me oferece uma escrava': alforrias por substituição na Bahia" (Reis 2021).

24 For eighteenth-century Salvador, see also Souza (2014). In the Bahian hinterland, proportions could be higher: for the eighteenth-century mining town of Rio de Contas, see Almeida 2012b: 175 (92 cases, $4.7 \%$ of paid manumission); and for the following century, in the same region, Almeida 2012a: 64 (25 cases, or 5.5\% of paid freedom). Elsewhere in Brazil, here are a few examples: for Porto Alegre, see Moreira and Tassoni 2007: 65 (122 out of 10,055 total for the period 1748-1888); for Sabará (Minas Gerais), see Higgins 1999: 40-41 (3 percent of all manumissions, but does not indicate numbers). 
teaching the local language, some Catholic doctrine, and, above all, a work routine, none of which was obtained without a measure or a lot of violence, an undertaking that in the Anglophone slave societies of the Caribbean and Mainland North America was defined by the expression "to break the slave". In other words, from a few months to a couple of years, enslaved masters put their slaves to work for them, probably shoulder to shoulder in many cases, while their substitutes were being trained. Enslaved slaveowners usually had to provide their masters with substitutes who would perform the same tasks as those performed until then by manumitted slaves. This situation emerges in manumission documents in which the occupation of the slaves involved was declared. In 1809, Ventura, a bricklayer, offered another bricklayer as a substitute; in 1826, Izidorio, a cook, paid his freedom with Antonio, also a cook, plus 541 mil-reis; in 1828, Gregorio, a sedan chair porter, gave his master another sedan chair porter; in 1832, Antonio, a chair porter, was substituted in slavery by "a slave of his also a chair porter of the Nagô nation", in the words of Antonio's master, plus 150 mil-reis. ${ }^{25}$

A list of such cases could go on and on, but I will finish with one that is particularly telling. In a freedom paper from 1849, Gertrudes's master, a shopkeeper, decided to be very specific about another Gertrudes whom he had agreed to receive as a substitute under his yoke. He would accept the new Gertrudes only after she was trained to perform all tasks the freed female slave had been performing, namely wash the family clothes, go out shopping, deliver milk to her master's clientele, in sum, "attend in the same way to the services that she [the freedom bidder] is used to do for me". Training the new Gertrudes took two years and a half, between 1849 and 1852, during which time her labour was consumed by her enslaved mistress, while the outgoing enslaved woman augmented her productivity to her master's joy. ${ }^{26}$

It is not a coincidence that both enslaved women in this transaction had the same name, Gertrudes, and belonged to the same African nation, Nagô, a sign that Antonio José Lobo, who was granting freedom, demanded no less than an exact replica of the person leaving his service, an impressive example of master class reification of the enslaved African. I found seventeen transactions that fit the same-name pattern; however, many other substitute slaves, registered nameless in the freedom papers for still being "pagans", would have later received the same names of the slaves being manumitted once the deal was closed, the substitute baptized and integrated to the new owners' households. Finally, yet equally important, the substitute slave brought a considerable advantage to the grantor of manumission, who replaced an older slave with a younger one, which was overwhelmingly the case of the Africans used as substitutes, usually, as I mentioned earlier, recently imported negros novos.

25 APEB, $L N T$, 160, fl. 289; LNT 217, fl. 42v.; LNT, 223, f. 35v; and LNT 242, fls. 267v-268.

26 APEB, $L N T, 303$, fl. 23v. 
Some masters, however, considered their slaves too valuable to be exchanged on a par with the substitute slave, even if healthy and younger. In such circumstances, masters would then ask as substitutes either two slaves or, more often, a combination of one slave and money. When manumission prices were set in figures, usually the buyer of freedom was evaluated in the local currency as well as the substitute, and the difference paid in cash, a difference, of course, that never favoured the freedom seeker. Of the manumission bids in this study, eleven involved two or three substitutes, and 36 a mix of one slave plus money, meaning that the manumitted slave had been able to amass savings valued more than the price he had eventually paid for his substitute. This also suggests that, in many cases, the outgoing slave had not bought a captive intended for immediate substitution, but instead to be hired out and thus increment his/ her enslaved master/mistress's peculium, and only later offer him or her as a substitute in slavery.

Unlike baptism records, in which slave women were roughly half the number of men, in freedom papers they surpassed men by more than two to one, both as slaveholders and as substitute slaves. In whole numbers: 276 female against 136 male freedom bidders; 271 women, 150 men, and 12 substitutes for whom gender information was not available. Because they were replacing themselves in manumission bids, the overwhelming majority of slaves paid their freedom with substitutes of the same sex. However, African access to the negros novos market was to a large extent controlled by men - probably due to their more intimate connections with the slave trade business community - who, in turn, sold to enslaved women captives that they had already trained and sometimes baptized. Maybe it was easier for a man to control a recently arrived African, to train and resell him or her for a profit. Enslaved buyers constituted an important clientele, and they were primarily women, prosperous petty merchants in their majority, with a buying power higher than that of enslaved men, at least considering those who wished to acquire slaves to replace them in bondage. ${ }^{27}$

There were indeed market circuits that do not emerge in baptismal records and are only insinuated in manumission papers. In other words, circuits that rarely appear in conventional sources because they were informal. The private bill of sale that I mentioned before is evidence of this: the enslaved Manoel Joaquim Ricardo bought an enslaved girl, received a bill of sale from the seller, and only used it again when he needed to prove he was her legitimate owner.

As for the ethnic background of the enslaved masters and their substitutes, they are roughly the same in both baptism and manumission records. The vast majority

27 As I said, manumission records do not mirror baptisms when dealing with this theme, beginning with the numbers. However, as I also mentioned, church records are often imprecise or lost. In addition, manumission bidders, in their majority, seems to have bought their slaves without leaving trace of such transactions in surviving documents. 
were African born, which reflected their proportions in the enslaved population and the fact that locally born slaves were more often manumitted free of charge. Also, Africans, particularly African women, controlled urban occupations that were especially profitable, such as street vending and other small business ventures. Thus, in the Baptism records, I detected only five Brazilian-born enslaved masters (or 8 percent) out of 64 with known origin. In manumission records, I identified a higher proportion: 89 out of 403, or 22 percent with known origin. Among the substitutes, the presence of Brazilian-born slaves was minimum, only eight out of 283 of known origin.

Among the Africans, specifically, the Yoruba-speaking Nagô made up the majority, which reflected the direction of the transatlantic slave trade to Bahia in the nineteenth century. The Nagôs largely prevailed in manumission documents, especially as substitutes. They represented 29 percent of the 295 manumitted Africans with known nations, and 51 percent of the 237 their substitutes, also considering only those with known nations. However, I am quite sure that the 32 manumitted slaves and the 188 substitutes whose nations are omitted in the sources were Nagôs in their vast majority.

Figure 1: African Nations of Freed Persons and Their Substitutes

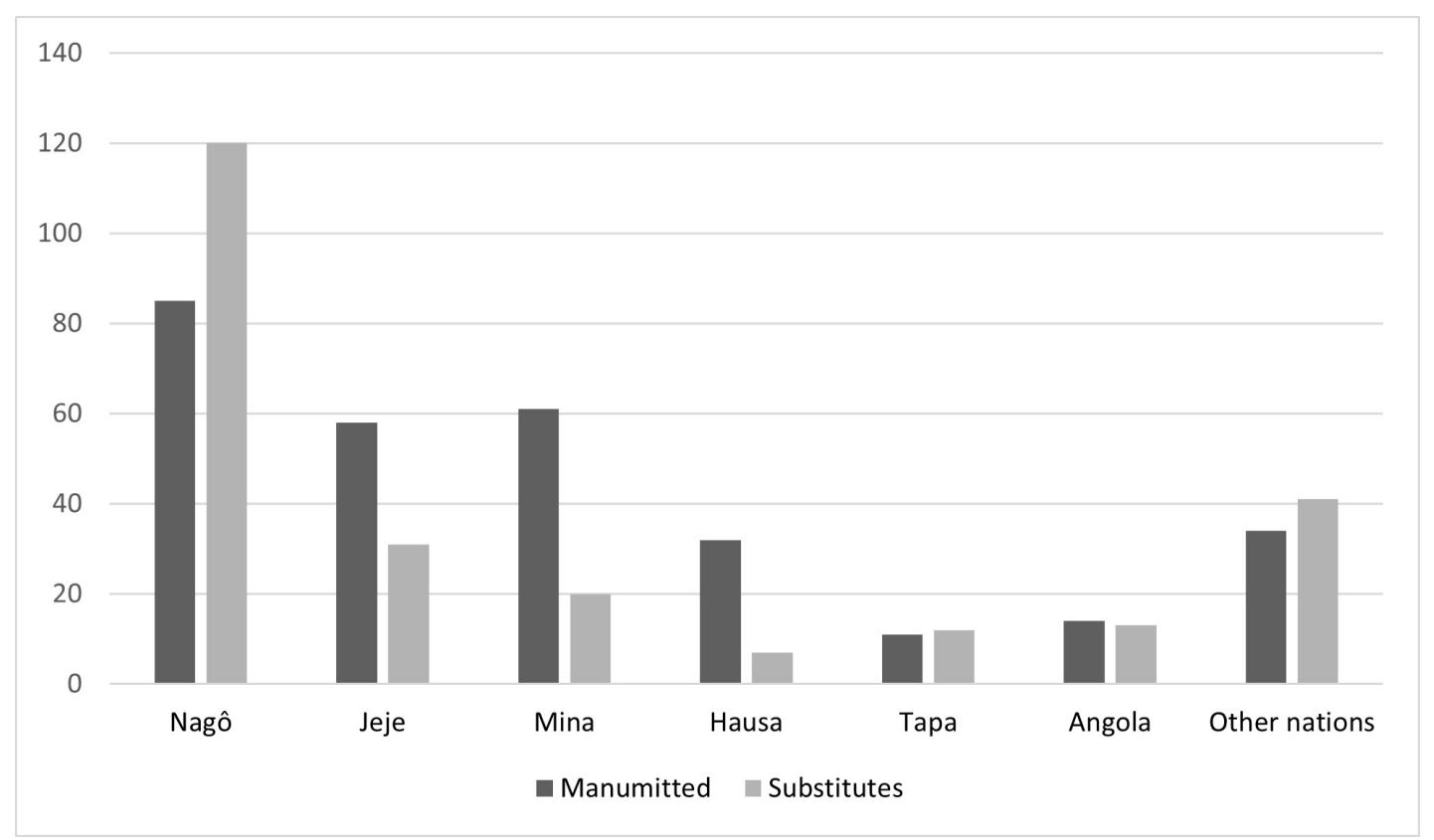

Source: APEB, Livro de Notas do Tabelião.

Often African enslaved slaveowners and their slaves belonged to the same nation. That was the case of 25.6 percent of the Africans in baptism records and an even higher 33 percent in manumission records. Among the Nagô, this proportion reached 57 percent in manumission bids, and if we consider only women, the rate was even higher, 61 percent. Evidently, slaves interested in buying other slaves for whatever 
purpose were limited in their option by who the market had to offer. In the period under scrutiny, Nagô women and men flooded the slave trade warehouses in Salvador, especially in the 1820s through the 1840s. In other words, if a Nagô wished to manumit herself or himself using the substitution method, she or he would almost inevitably have to buy someone belonging to the same nation. In fact, buyers from any ethnic background did not have much choice besides buying Nagôs. Thus, of the 44 Jejes for whose substitutes we know their nations, only 27.3 percent offered other Jejes, and of 19 Hausas, only one offered another Hausa. They were thus replaced in bondage by Nagôs in their majority.

Substitutions involving slaves of the same nation suggest that slavery in Brazil subverted a golden rule of slavery in Africa, namely the taboo against enslaving individuals of the same ethnic group, except under exceptional circumstances such as to avoid death from famine or the punishment of a crime (Finley 1968; Meillassoux 1995; Patterson 1982). ${ }^{28}$ However, the enslavement of victims of intestine wars in Africa became a common feature in the nineteenth century, for instance, in Yorubaland and Hausaland, two important places of origin for thousands of Bahian slaves, be they warriors captured in the battlefields or villagers living on the path of a moving army and independent marauders. Perhaps nothing was more efficacious than a war to rip cultural values and collective solidarity apart. Therefore, the desertion from customs, in this case enslaving inside one's community, had been installed even before African captives reached Bahia. The enslavable person was by definition the uprooted, the expatriate, the foreigner, but also those who had become enemies for commercial, judicial, political, or family disputes, and then redefined as "the other", a stranger in the nest. A famous case among the Oyo Yoruba, the young Samuel Crowther (a future Anglican bishop) was kidnapped and sold by Oyo Muslims who belonged to his own ethnic group, although affiliated with a different religion. Or Rufino José Maria, also from Oyo, who was captured and sold as a slave by Hausa Muslims, people belonging to the same religion as his but members of a different ethnic group (Crowther 1842: 274; Reis et al. 2020; Meillassoux 1995; Patterson 1982).

It is possible, however, that in Bahia the rule of exogamous enslavement only was still observed among Africans who belonged to specific ethnic communities. In that sense, presumably, a Nagô from Oyo would not enslave another Nagô from Oyo, or a Hausa from Katsina avoided enslaving a Hausa from Katsina, especially a fellow Muslim. However, if we consider that ethnicity was not a fixed, essentialized condition and that in Bahia, Nagô from different parts of Yorubaland - and this was true for other African nations as well - came to constitute a recognizable ethnic formation, whose members had even adopted the convention of calling each other parentes (relatives), 
the inevitable conclusion is that slavery in the western shores of the Atlantic did affect protocols and meanings of group solidarity and mutual protection that existed in Africa. Parentes enslaved parentes. One explanation could be that Africans who had been living for years in Bahia, who had already absorbed many of their masters' cultural traits, including their culture of chattel slavery, who lived side by side with freed Africans who owned slaves, in other words, the African ladino (as opposed to boçal, as the negro novo was called), be they enslaved or freed, saw the recently arrived captive African as "the other", a foreigner. In this aspect, the ladino represented a social construction that was crucial for the formation of African nations in Brazil. Therefore, the boçal from Oyo, Egba, llesa, or ljebu would not become Nagô the moment he or she disembarked from the slave ship in Bahia. The ladino did not consider the boçal a parente and enslaving him or her did not disturb his (the ladino's) sleep at night. ${ }^{29}$ African ethnic communities (nations) were not egalitarian polities. They convened people of different social standings, namely enslaved and freed Africans, who could be absolutely disposed, like the majority was, or could eventually own property that included other Africans.

\section{Conclusion}

Slaves who owned slaves made liberal use of common law rights to overcome their condition and to succeed as freed persons eventually. Although they were not the norm, their experience adds another dimension to the possibilities carved out by Africans in Brazil to advance their own interests under slavery, in this case to the detriment of other Africans. This would not be feasible, of course, if they did not explore specific conjunctures or contexts, such as access to relatively cheap African captives while the transatlantic slave trade subsisted, especially when it intensified, creating a sort of buyers' market. Accompanying a collective response to the imminent end of the slave trade, the enslaved slaveowners displayed a remarkable understanding of the Atlantic mercantile dynamics. Call it business acumen, sense of opportunity, entrepreneurship, favourable mercantile connections; nevertheless, none of this would have been feasible outside the realm of specific social relations, primarily those between the enslaved masters and their masters.

The enslaved slaveowners' strategy depended upon a good relationship and favourable negotiations with their owner that would allow them, first, to amass a sizable peculium; second, to invest it in slaves; third, to make their slaves work for them and enjoy in other ways their human property; and fourth, to eventually use - immediately or in the long-run - their slaves as substitutes in manumission transactions. All of these steps required being on good terms with their masters. In the process, the enslaved master

29 Some studies have already pointed out that African freed persons enslaved their ethnic kin. See Oliveira 1996: 187-189; Castillo and Parés 2007; and Reis 2015: 268-280, among others. 
acquired a new status in the local society, especially in the slave community itself: they were still enslaved, yes, but they were simultaneously slave masters, meaning that they could display one of the main symbols of freedom (and the main investment asset) in a slave society, namely property in people. The enslaved master combined an overlapping social condition, overlapping labour forms, and a blurred frontier between slavery and freedom. Many chose to exist in this liminal status rather than risk freedom and, as a result, forfeit the immediate protection of a master, a very important matter in a society where freedom often precarious (Chalhoub 2014), even more so for the African-born freed person, who did not become a citizen following manumission as did those born in Brazil. However, probably the majority of enslaved Africans who bought other slaves did so with the specific purpose of obtaining manumission through substitution, for which a specific set of negotiation procedures and arrangements were set in motion between the parties involved.

Slaves who owned slaves did not challenge the system, of course; on the contrary, they abided by its rules and in a way reinforced them, even if their mere existence challenged, symbolically at least, the conventions - or a certain conventional model - of modern-era chattel slavery. From the point of view of their masters, as I said, the expectation was to have at their disposal a more efficient, reliable workforce, which came in combination with loyalty, obedience, and gratitude, guaranteeing that inequality and political dominion persisted unabated. In sum, as a slave master, it was hoped that a slave would better understand what a hierarchical order under slavery was supposed to be and to mean.

Players in an intriguing power game, both enslaved slaves and their masters were rather conscious that this arrangement should not weaken the chain of command in society. That was not negotiable, and there were legal mechanisms to enforce it. After all, under positive law, whatever belonged to a slave belonged to his or her master, including the authority over the slave of a slave in dealings before the judicial and other spheres of institutional power. This was not always negative, though. Enslaved slaveowners often counted on their masters' help to control their own slaves: for instance, in seeking help from the police to capture a fugitive slave of a slave. ${ }^{30}$

This web of convivial relations also involved the slaves of slaves, of course, who could often be caught under the control, exploitation or even tyranny of two masters, both of whom they had to satisfy in terms of work, obedience, and deference if they were to avoid punishment, unwanted sale, and obstacles to a future manumission. On the other hand, the slave of an enslaved master would, with time, have learned or at least tried to use the master of his master as a mitigating moral force against ill-treatment.

30 See for instance Antonio Muniz Barreto de Aragão to the chief of police, 14 de fevereiro de 1849 , APEB, Polícia, maço 6306. 
But let us not go too far in that direction. Considering that the experience of being an enslaved master often came together with that of a much more autonomous life, which included living apart from one's master, in the end, slaves of slaves would have to rely on their own ability to negotiate, without mediation, the terms of their bondage. Consider the way the above mentioned Manoel Joaquim Ricardo treated his slaves as a freedman: he sold several of them out of Bahia, including creoles born of his African female bondwomen; he chased his fugitive slaves mercilessly, and, when they were caught, punished them with whippings or by selling them out of the province - and absconding was evidence that he was not a nice master. In addition, he charged high prices for their slaves' manumission; and, in contrast with his master, who manumitted almost all of his slaves at death, Ricardo did not free any of his when he wrote his will (Reis 2016).

Table 2: Enslaved Slaveowners and Rebel Slaves in Bahia, 1800-1850

\begin{tabular}{|l|r|r|r|}
\hline \multicolumn{1}{|c|}{ Years } & \multicolumn{1}{c|}{$\begin{array}{c}\text { Enlsaved } \\
\text { Slaveowners }\end{array}$} & $\begin{array}{l}\text { Manumission by } \\
\text { Substitution }\end{array}$ & $\begin{array}{c}\text { Revolts \& } \\
\text { Conspiracies }\end{array}$ \\
\hline To 1810 & 10 & 44 & 2 \\
\hline $1811-15$ & 13 & 37 & 3 \\
\hline $1816-20$ & 8 & 39 & 5 \\
\hline $1821-25$ & 8 & 56 & 16 \\
\hline $1826-30$ & 33 & 114 & 1 \\
\hline $1831-35$ & 9 & 46 & 4 \\
\hline After 1835 & 18 & 74 & 32 \\
\hline Total & 99 & 410 & \\
\hline
\end{tabular}

Source: ACMS, Registros de batismos de Salvador; APEB, Livros de Notas do Tabelião; and author's slave revolts databank.

Finally, consider Table 2, which indicates that while many slaves bought other slaves for a number of reasons, others, more numerous, revolted against slavery. Paternalistic modes of control did not work for or were not even tried on them. Therefore, the same slave market that multiplied the beneficiaries and greased the wheels of the system, also reproduced the slave rebel. There was indeed a close correspondence between the steep increase in the number of imported Africans and incidents of collective slave resistance. Clearly, the rebels were negros novos in their majority, even though their leaders would more likely be ladino Africans. One of these rebellions, in April 1830, a time of feverish slave trade dealings, consisted in an assault of a warehouse in Salvador where newly arrived Africans had been waiting to be sold, a few of whom 
adhered to the uprising. A clear protest against the slave trade in a moment of intense activity, the revolt was quickly put down in a bloodbath (Reis 2003).

\section{Abbreviations}

ACMS: Arquivo da Cúria Metropolitana de Salvador

LRBCP: Livro de registros de batismos da Conceição da Praia

APEB: Arquivo Público do Estado da Bahia

LNT: Livro de Notas do Tabelião

\section{Bibliography}

Almeida, Katia Lorena N. (2012a): Alforrias em Rio de Contas, Bahia, século XIX, Salvador: EDUFBA.

(2012b): Escravos e libertos nas Minas do Rio de Contas, Bahia, século XVIII [Doctoral dissertation], Salvador: Universidade Federal da Bahia.

Andrade, Maria José (1988): A mão-de-obra escrava em Salvador, 1811-1888, Salvador: Currupio.

Bauer, Raymond A.; and Bauer, Alice H. (1971): "Day-to-Day Resistance to Slavery." In Bracey Jr., J. H. et al. (eds.). American Slavery: The Question of Resistance (Belmont, CA: Wadsworth Publishing Co.), 37-60.

Belini, Ligia (1988): "Por amor e por interesse: a relação senhor-escravo em cartas de alforria", in: Reis, João José (ed.), Escravidão e invenção da liberdade, São Paulo: Brasiliense, 73-86.

Bethell, Leslie (1970): The Abolition of the Brazilian Slave Trade: Britain and the Slave Trade Question, 1807-1869, Cambridge: Cambridge University Press.

Buckland, W. W. (1908): The Roman Law of Slavery: The Condition of Slave in Private Law from Augustus to Justinian, Cambridge: Cambridge University Press.

Castillo, Lisa Earl and Parés, Luis Nicolau (2007): "Marcelina da Silva e seu mundo: novos dados para uma historiografia do candomblé ketu", in: Afro-Ásia, 36, $111-151$.

Chalhoub, Sidney (2003): Machado de Assis, historiador, São Paulo: Companhia das Letras. 
(2014): A força da escravidão: ilegalidade e costume no Brasil oitocentista, São Paulo: Companhia das Letras.

Cortez Bremeu, Antonio (1749): Universo jurídico ou jurisprudência universal, canônica e cesarean etc, Lisbon: Oficina de Domingos Rodrigues.

Costa, Robson Pedrosa (2020): Os escravos do santo: uma história sobre paternalismo e transgressão nas propriedades beneditinas, séculos XVIII e XIX, Recife: UFPE.

Crowther, Samuel (1842): "Letter of Mr. Samuel Crowther to the Rev. William Jowett, in 1837", in: Schön, James Fredrick and Crowther, Samuel (eds.), Journals of the Rev. James Frederick Schön and Mr. Samuel Crowther: Who, Accompanied the Expedition Up the Niger, in 1841, in Behalf of the Church Missionary Society, London: Hatchard and Son; Nisbet and Co., 274.

Díaz, María E. (2000): The Virgin, the King, and the Royal Slaves of El Cobre: Negotiating Freedom in Colonial Cuba, 1670-1780, Stanford: Stanford University Press.

Eltis, David and Richardson, David (2008): "A New Assessment of the Transatlantic Slave Trade", in: Eltis, David and David Richardson (eds.), Extending the frontiers: Essays on the new transatlantic slave trade database, New Haven: Yale University Press, 1-60.

(eds.) (2008): Extending the frontiers: Essays on the new transatlantic slave trade database, New Haven: Yale University Press.

Finley, Moses (1968): "Slavery", in: Sills, David L. (ed.), International Encyclopedia of the Social Sciences [14], New York: MacMillan Co. and The Free Press, 307-313.

(1980): Ancient Slavery and Modern Ideology, New York: The Viking Press.

Florentino, Manolo (1997): Em costas negras: uma história do tráfico de escravos entre a África e o Rio de Janeiro, São Paulo: Companhia das Letras.

Frank, Zephyr L. (2004): Dutra's World: Wealth and Family in Nineteenth-Century Rio de Janeiro, Albuquerque: University of New Mexico Press.

Fuente, Alejandro de la (2004): "Slave Law and Claims-Making in Cuba: The Tannenbaum Debate Revisited", in: Law and History Review, 22, 2, 339369. 
Genovese, Eugene (1974): Roll Jordan Roll: The World the Slaves Made, New York: Pantheon.

Higgins, Kathleen J. (1999): "Licentious Liberty" in a Brazilian Gold-Mining Region: Slavery, Gender, and Social Control in Eighteenth-Century Sabará, Minas Gerais, University Park, PA: The Pennsylvania State University Press.

Klein, Herbert S. and Luna, Francisco Vidal (2009): Slavery in Brazil, Cambridge: Cambridge University Press.

Law, Robin (1977): The Oyo Empire, c. 1600-c. 1836: A West African Imperialism in the Era of the Atlantic Slave Trade, Oxford: Clarendon Press.

Malheiros, Perdigão ([1867] 1976): A escravidão no Brasil: ensaio histórico, jurídico, social, Rio de Janeiro: Vozes.

Mattoso, Kátia M. de Queirós (1979): Être esclave au Brésil. XVle-XIXe siècle, Paris: Hachette.

Meillassoux, Claude (1995): Antropologia da escravidão: o ventre de ferro e dinheiro, Rio de Janeiro: Zahar.

Mello e Souza, Laura de; Furtado, Junia F. and Bicalho, Maria Fernanda (eds.) (2009): O governo dos povos, São Paulo: Alameda.

Moreira, Paulo Roberto Staudt and Tassoni, Tatiani de Souza (2007): Que com seu trabalho nos sustenta: as cartas de alforria de Porto Alegre (1748-1888), Porto Alegre: EST Edições.

Nardi, Jean-Baptiste (1996): O fumo brasileiro no período colonial: Lavoura, comércio e administração, São Paulo: Brasiliense.

Nishida, Mieko (1993): "Manumission and Ethnicity in Urban Slavery: Salvador, Brazil, 1808-1888", in: The Hispanic American Historical Review, 73, 3, 361-391.

Nogueira, Gabriela Amorim (2011): "Viver por si, viver pelos seus": famílias e comunidades de escravos e forros no "Certam de Sima do Sam Francisco" (1730-1790) [Master's Dissertation]. Universidade do Estado da Bahia.

Oliveira, Maria Inês Côrtes de (1996): "Viver e morrer no meio dos seus: Nações e comunidades africanas na Bahia do século XIX", in: Revista USP, 28, 174193.

Patterson, Orlando (1982): Slavery and Social Death: A Comparative Study, Cambridge, MA: Harvard University Press. 
Peel, John D. Y. (2000): Religious Encounter and the Making of the Yoruba, Bloomington and Indianapolis: Indiana University Press.

Raggi, Giuseppina; Figueirôa-Rêgo, João and Stumpf, Roberta Giannubilo (eds.) (2017): Salvador da Bahia. Interações entre América e África, séculos XVI-XIX, Salvador, Lisboa: EDUFBA; Centro de História d'Aquém e d'Além-Mar.

Reis, João José (ed.) (1988): Escravidão e invenção da liberdade, São Paulo: Brasiliense.

(2003): Rebelião escrava no Brasil: a história do levante dos malês em 1835, São Paulo: Companhia das Letras.

(2015): Divining Slavery and Freedom: The Story of Domingos Sodré, an African Priest in Nineteenth-Century Brazil, New York: Cambridge University Press.

(2016): "De escravo a rico liberto: a trajetória do africano Manoel Joaquim Ricardo na Bahia oitocentista", in: Revista de História, 174, 15-68.

(2019): Ganhadores: a greve negra de 1857 na Bahia, São Paulo: Companhia das Letras.

(2021) "'Por sua liberdade me oferece uma escrava': alforrias por substituição na Bahia", Afro-Ásia, 63 (forthcoming).

Reis, João José; Gomes, Flávio and Carvalho, Marcus (2020): The Story of Rufino, New York: Oxford University Press.

Reis, João José and Silva, Eduardo (1989): Negociação e conflito: a resistência negra no Brasil escravista, São Paulo: Companhia das Letras.

Schön, James Fredrick and Crowther, Samuel (eds.) (1842): Journals of the Rev. James Frederick Schön and Mr. Samuel Crowther: Who, Accompanied the Expedition Up the Niger, in 1841, in Behalf of the Church Missionary Society, London: Hatchard and Son; Nisbet and Co.

Schwartz, Stuart (2001): Escravos, roceiros e rebeldes, Bauru: EDUSC.

Scott, James C. (1992): Domination and the Arts of Resistance: Hidden Transcript, New Haven: Yale University Press.

Sills, David L. (ed.) (1968): International Encyclopedia of the Social Sciences [14], New York: MacMillan Co. and The Free Press. 
Souza, Daniele Santos de (2017): "Preto cativo nada é seu': escravos senhores de escravos na Cidade da Bahia no século XVIII", in: Raggi, Giuseppina; Figueirôa-Rêgo, João and Stumpf, Roberta Giannubilo (eds.), Salvador da Bahia. Interações entre América e África, séculos XVI-XIX, Salvador, Lisboa: EDUFBA; Centro de História d'Aquém e d'Além-Mar, 55-75.

(2014): "Nos caminhos do cativeiro, na esquina com a liberdade: alforrias, resistências e trajetórias individuais na Bahia setecentista", in Gabriela Sampaio et. al. (eds.), Barganhas e querelas da escravidão: tráfico, alforria e liberdade (Salvador: Edufba, 2014), 110-111.

Sweet, James (2011): Domingos Álvares: African Healing, and the Intelectual History of the Atlantic World, Chapel Hill: North Carolina University Press.

TSTD (2019): The Transatlantic Slave Trade: An Expanded and Online Database, at: http://www.slavevoyages.org (Last access 01.05.2019).

Weaver, P. R. C. (1964): "Vicarius and Vicarianus in the Familia Caesaris", in: Journal of Roman Studies, 54, 1-2, 117-128.

Wissenbach, Maria Cristina Cortez (2009): "Cirurgiões e mercadores nas dinâmicas do comércio atlântico de escravos (séculos XVIII e XIX)", in: Mello e Souza, Laura de; Junia F. Furtado and Maria Fernanda Bicalho (eds.), O governo dos povos, São Paulo: Alameda, 106-149. 


\section{Working Papers published since 2017:}

1. Maria Sybilla Merian International Centre for Advanced Studies in the Humanities and Social Sciences Conviviality-Inequality in Latin America (Mecila) (2017): "Conviviality in Unequal Societies: Perspectives from Latin America: Thematic Scope and Preliminary Research Programme".

2. Müller, Gesine (2018): "Conviviality in (Post)Colonial Societies: Caribbean Literature in the Nineteenth Century".

3. Adloff, Frank (2018): "Practices of Conviviality and the Social and Political Theory of Convivialism".

4. Montero, Paula (2018): "Syncretism and Pluralism in the Configuration of Religious Diversity in Brazil".

5. Appadurai, Arjun (2018): "The Risks of Dialogue".

6. Inuca Lechón, José Benjamín (2018): "Llaktapura sumak kawsay / Vida plena entre pueblos. Un concepto emancipatorio de las nacionalidades del Ecuador".

7. Wade, Peter (2018): "Mestizaje and Conviviality in Brazil, Colombia and Mexico".

8. Graubart, Karen (2018): "Imperial Conviviality: What Medieval Spanish Legal Practice Can Teach Us about Colonial Latin America".

9. Gutiérrez, Felipe Castro (2018): "La violencia rutinaria y los límites de la convivencia en una sociedad colonial".

10. Wasser, Nicolas (2018): "The Affects of Conviviality-Inequality in Female Domestic Labour".

11. Segura, Ramiro (2019): "Convivialidad en ciudades latinoamericanas. Un ensayo bibliográfico desde la antropología".

12. Scarato, Luciane (2019): "Conviviality through Time in Brazil, Mexico, Peru, and Río de la Plata".

13. Barreneche, Osvaldo (2019): "Conviviality, Diversidad, Fraternidad. Conceptos en diálogo".

14. Heil, Tilmann (2019): "Conviviality on the Brink". 
15. Manzi, Maya (2019): "Fighting against or Coexisting with Drought? Conviviality, Inequality and Peasant Mobility in Northeast Brazil".

16. Guiteras Mombiola, Anna (2019): "School Centres for 'Savages': In Pursuit of a Convivial Sociability in the Bolivian Amazon".

17. Costa, Sérgio (2019): "The Neglected Nexus between Conviviality and Inequality".

18. Banzato, Guillermo (2019): "Soberanía del conocimiento para superar inequidades. Políticas de Acceso Abierto para revistas científicas en América Latina".

19. Gil Montero, Raquel and Albiez, Sarah (2019): "Conviviality as a Tool for Creating Networks: The Case of an Early Modern Global Peasant Traveler".

20. Briones, Claudia (2019): "Políticas contemporáneas de convivialidad. Aportes desde los pueblos originarios de América Latina".

21. Rojas Scheffer, Raquel (2020): “Articulating Differences and Inequalities: Paid Domestic Workers' and Housewives' Struggles for Rights in Uruguay and Paraguay".

22. Potthast, Barbara (2020): "Mestizaje and Conviviality in Paraguay".

23. Mahile, Alejandra (2020): “¿Legados prestigiosos? La revalorización del sustrato cultural indígena en la construcción identitaria argentina,entre fines del siglo XIX y los años treinta".

24. Segsfeld, Julia von (2020): "Ancestral Knowledges and the Ecuadorian Knowledge Society".

25. Baldraia, Fernando (2020): “Epistemologies for Conviviality, or Zumbification".

26. Feltran, Gabriel (2020): "Marginal Conviviality: On Inequalities and Violence Reproduction".

27. Rojas Scheffer, Raquel (2020): "Physically Close, Socially Distant: Paid Domestic Work and (Dis-)Encounters in Latin America's Private Households".

28. Gil Montero, Raquel (2020): "Esclavitud, servidumbre y libertad en Charcas".

29. Manzi, Maya (2020): "More-Than-Human Conviviality-Inequality in Latin America". 
30. Klengel, Susanne (2020): "Pandemic Avant-Garde: Urban Coexistence in Mário de Andrade's Pauliceia Desvairada (1922) After the Spanish Flu".

31. Gomes, Nilma L. (2021): "Antiracism in Times of Uncertainty: The Brazilian Black Movement and Emancipatory Knowledges".

32. Rocha, Camila (2021): "The New Brazilian Right and the Public Sphere".

33. Boesten, Jan (2021): "Violence and Democracy in Colombia: The Conviviality of Citizenship Defects in Colombia's Nation-State".

34. Pappas, Gregory F. (2021): "Horizontal Models of Conviviality or Radical Democracy in the Americas: Zapatistas, Boggs Center, Casa Pueblo".

35. Gutiérrez Rodríguez, Encarnación (2021): "Entangled Migrations: The Coloniality of Migration and Creolizing Conviviality".

36. Reis, João José (2021): "Slaves Who Owned Slaves in Nineteenth-Century Bahia, Brazil" 


\section{Contact}

Coordination Office

Maria Sybilla Merian International Centre

for Advanced Studies in the Humanities and

Social Sciences

SPONSORED BY THE

Conviviality-Inequality in Latin America

Rua Morgado de Mateus, 615

São Paulo - SP

CEP 04015-051

Brazil

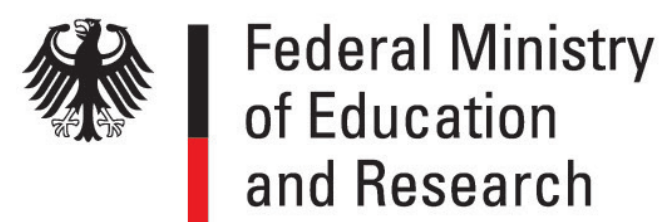

mecila@cebrap.org.br 

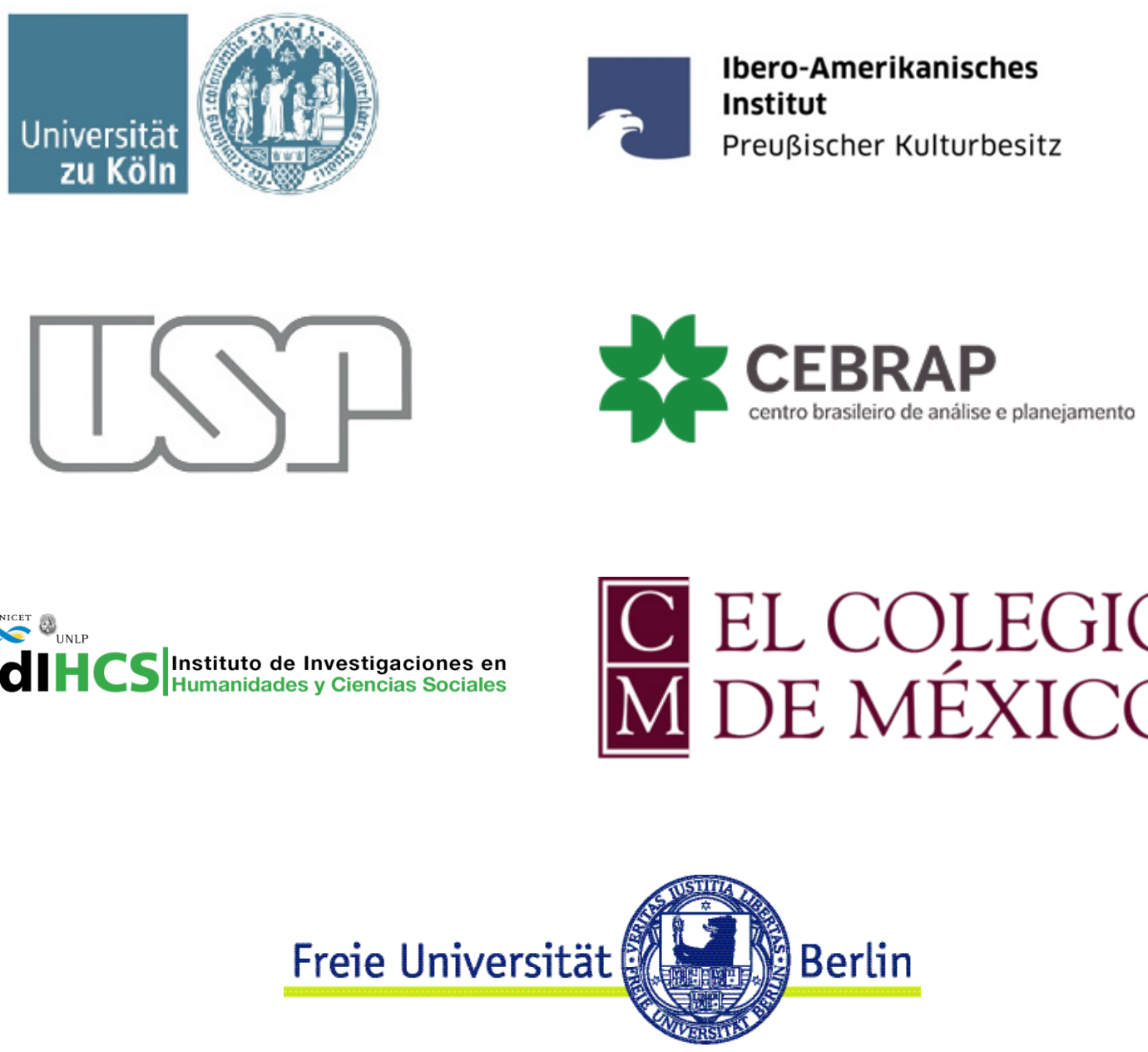

The Maria Sibylla Merian International Centre for Advanced Studies in the Humanities and Social Sciences Conviviality-Inequality in Latin America (Mecila) was founded in April 2017 by three German and four Latin American partner institutions and is funded by the German Federal Ministry of Education and Research (BMBF). The participating researchers investigate coexistence in unequal societies from an interdisciplinary and global perspective. The following institutions are involved: Freie Universität Berlin, Ibero-Amerikanisches Institut/ Stiftung Preußischer Kulturbesitz, Universität zu Köln, Universidade de São Paulo (USP), Centro Brasileiro de Análise e Planejamento (CEBRAP), IdIHCS (CONICET/Universidad Nacional de La Plata), and El Colegio de México. Further information at http://www.mecila.net. 